\title{
LOGISTIC REGRESSION AS INSTRUMENT FOR ANALYZING INFLUENCE OF REMMITANCES ON ECONOMIC GROWTH
}

http://doi.org/

(C) Oleskiv I., Mirzoieva D., 2020

In the article, the influence of remittances on economics growth in Ukraine was researched. In order to conduct the research the logistics regression was applied. Volumes of consumption, export and import were included into the logistics model as variables, which contribute to calculation of GDP. By changing remittances, we identified their level, which will lead to GDP growth. Specifically, it was found out that economic growth would be achieved if remittances will increase by $2 \%$ ceteris paribus.

Key words: remittances, consumption, logistic regression, GDP growth

\section{Problem statement and its relevance}

Growth of GDP is an important issue, which was widely investigated in the literature. There are a significant number of research of economics growth conducted for developed and developing countries. At the same time, the number of research conducted for transition economies are quite limited. Moreover, the research of economic growth usually lacks forecasting. While researching the problem we should consider the issues related to the fact that economic growth for transition economies is strongly related to the volume remittances. Specifically for Ukraine share of remittances in GDP reached almost $11 \%$ in 2019 (World Bank, 2020). Consequently, their impact on national economy will depend on domestic conditions and macroeconomic parameters, which are related to remittances. For instance, from prospect of additional source of income remittances can affect volumes of consumption, volumes of trade and, finally, growth of gross domestic product. As the result, the aim of the current article is to develop the method, which permits to identify the volume of remittances necessary to achieve economic growths.

\section{Literature review}

There is a debate in scientific literature about how economic growth should be estimated. Some researchers consider economic growth by analyzing the indicators of human capital (Mincer (1984), Mankiw, Romer and Weil (1992), Barro (2001), Pelinescu (2015)). The others consider estimation of economic growth using more traditional indicator of GDP growth (Weil, 2013). In current research we will use the former approach to presenting economic growth.

The other aspect, which sparkles the debate in academic literature, is the issue of remittance impact on economic growth. The noticeable number of researchers reported that for developing countries and for transition economies, remittances are important factors of economic growth (Ale, Akter and Islam (2018), Hussain and Anjum (2014), Olubiyi, 2014). Specifically, Ale, Akter and Islam (2018) reported that remittances have positive influence on economic growth of Bangladesh, India and Pakistan. Hussain and Anjum (2014) who identified positive correlation of remittances with economic growth in Pakistan confirmed the latter. Ale, Akter and Islam (2018) also found out that causality could be also reversed, which means that in some cases growth of GDP can lead to growth of remittances. Such situation was revealed in India. 


\section{Oleskiv I., Mirzoieva D.}

The research confirming positive influence of remittances were confirmed from the other part of the world, specifically for Nigeria (Olubiyi, 2014) Moreover, Javid and Arif (2012) underlined that remmitances had positive influence on poverty reduction. That finding was confirmed by the research of Ratha (2013). Interestingly, Rahman (2009) found weak causality between remittances and GDP growth in Bangladesh and India. At the same time Hassan and Shakur (2017) reported non-linear relationship between remittances and economic growth in Bangladesh. Specifically, the research conducted in the period between 1976 and 2012 showed that remittances have negative influence on GDP in earlier stages. However, on the later stages the influence becomes positive. The research conducted for Moldova showed that remittances can cause significant fluctuations for the economy (Le Heron and Yol, 2019).

The research conducted by Meyer and Shera (2017) for Albania, Bulgaria, Macedonia, Moldova, Romania and Bosnia Herzegovina found that remittances have positive impact on economic growth. Meyer and Shera (2017) reported that bigger share of remittances in GDP leads to their more significant impact on economic growth. The study was conducted in the period between 1999 and 2013. Meyer and Shera (2017) also suggested that further research of remittance influence on macroeconomic indicators required to be conducted.

\section{Article objective}

The aim of the current article is to estimate the level of remittances necessary to achieve economic growth.

\section{Data, methodology and results}

Considering the overall goal of the article, we suggested that the following methodology of the research:

1. Definition of variables representing the researched phenomenon.

2. Selection of method for data processing.

3. Interpretation of received research results.

Definition of variables. In order, to define the variables, which are going to be used in the model we applied the logic described further. For representation of economic growth was decided to use GDP growth, which is calculated as annual percentage growth rate of GDP at market prices based on constant local currency (World Bank, 2020). Remittances include personal transfers and compensation of employees received in Ukraine (World Bank, 2020). Final consumption consists of the sum of household final consumption expenditure and general government final consumption expenditure (World Bank, 2020). Other two dependent variables are exports and imports. Finally, consumption, export and import can be considered as endogenous factors, which can be controlled, while remittances exogenous. Annual data on GDP growth, share of consumption, remittance inflows, exports and imports as shares of GDP were extracted from World Development Indicators and covers 1995-2019 period (pic.1).

Selection of methods. The researchers applied various approaches to defining sources and factors of economic growth. Specifically, the classical approach to determining economic growth is the one, which is based on estimation of Cobb-Douglas function Solow (1988). Some researchers reported influence of labor, capital and innovations on economic growth using Cobb-Douglas function (Dugulena (2019)). Despite its attractiveness and technical perfectness a great number of researchers state that Cobb-Douglas function does not actually reflect the reality and empirical methods needs to be applied in order to research the problem. The new research of economic growth are more inclined to analyze dependencies between economic growth and its factors using regression methods, which comes out from the application of regression analysis. To estimate probability of growth of GDP we are going to employ logistic regression. As forecasting of specific value of economic growth unreliable under the impact of uncertainty, we are going to apply the method, which would demonstrate probability of economic growth. Moreover, logistic regression is relevant for such type of research as it does not require linear relationships between variable and predicts dependent variable as binary outcome. 

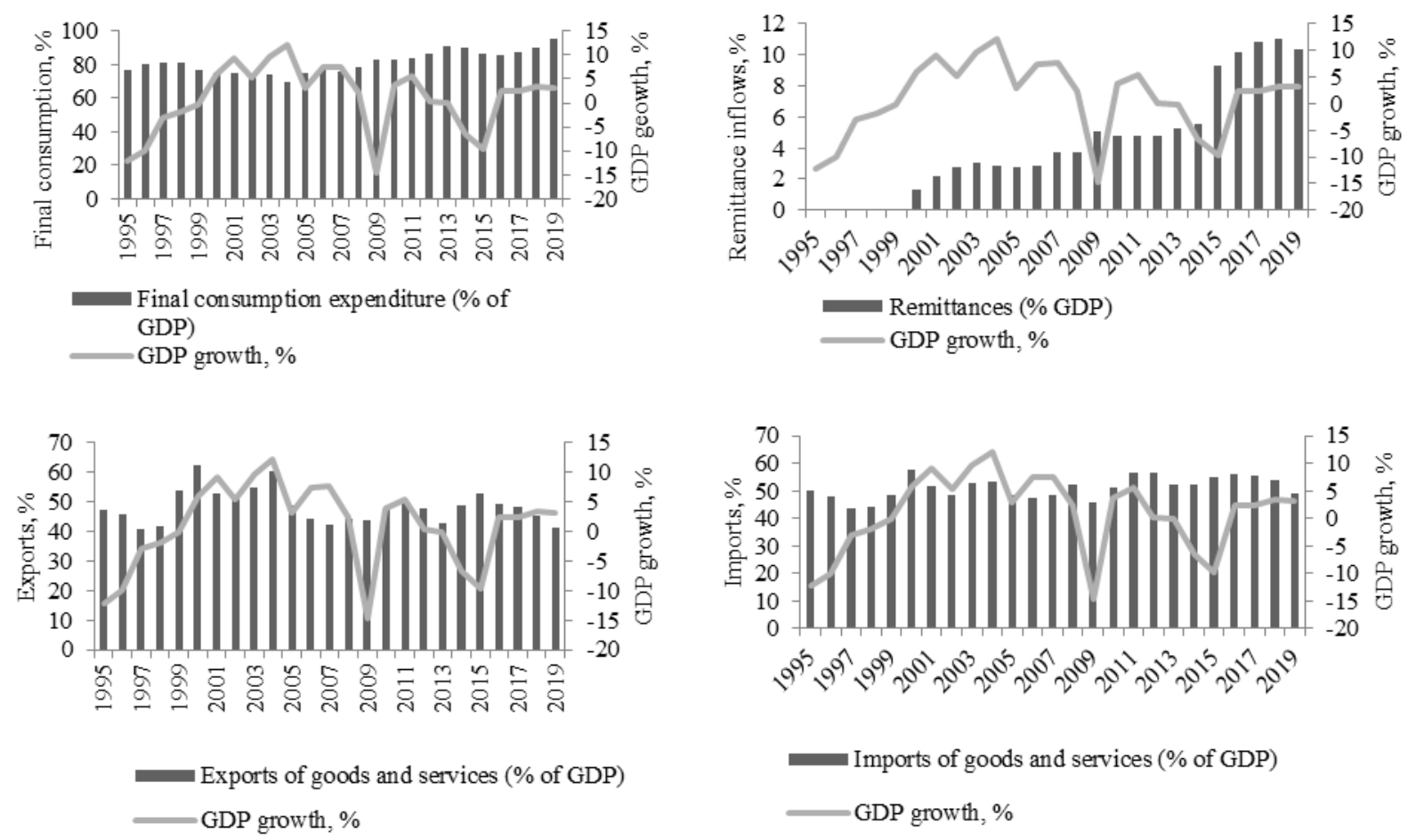

Pic. 1 Statistics on change of investigated parameters. Source: WDI, World Bank

For current estimation logistic regression is built as following (1).

$$
\ln \left(\frac{P_{g}}{1-P_{g}}\right)=b_{0}+b_{1} x_{1}+b_{2} x_{2}+b_{3} x_{3}+b_{4} x_{4}+\varepsilon
$$

where $P_{g}$ - probability of growth of GDP (1for growth years or 0 for declining years); $b_{0}, b_{1}, b_{2}, b_{3}, b_{4}-$ regression coefficients; $x_{1}$ - share of final consumption in GDP; $x_{2}$ - share of remittance inflows in GDP; $\mathrm{x}_{3}$ - share of exports in GDP; $\mathrm{x}_{4}$ - share of imports in GDP; $\varepsilon$ - error.

Estimation of this model consists of the following steps developed on the basis from Pregibon (1981) and our suggestions:

1. Estimation of linear regression model with GDP growth as dependent variable in binary form and chosen variables as independent variables.

2. Calculation of theoretical probabilities for each observation using received regression coefficients.

3. Calculation of sum of log-likelihoods, which demonstrates do theoretical probabilities correspond to actual data.

4. Optimization of regression coefficients to achieve maximal sum of log-likelihoods.

5. Testing of optimized model for adequacy by employing calculation of pseudo R-squared value (2) and chi-squared value (3).

$$
R^{2}=\frac{L L_{o}-L L_{f}}{L L_{o}}
$$

where $\mathrm{R}^{2}$ - pseudo R-squared value; $\mathrm{LL}_{\mathrm{o}}$ - overall probability, which is sum of sum of logarithm of growth years and sum of logarithm of declining years; $\mathrm{LL}_{\mathrm{f}}-$ sum log-likelihood of optimized model.

$$
\chi^{2}=2\left(L L_{f}-L L_{o}\right)
$$

where $\chi^{2}-$ chi squared value.

6. Construction of graphical test of fitness.

The results of regression (1) estimation by OLS estimator and optimization of its parameters in order to reach maximum likelihood is presented in tab. 1 . 
Results of logistic regression estimation. Source: author research

\begin{tabular}{|c|c|c|c|c|}
\hline Regressions & Regression equations & $\begin{array}{c}\text { Sum log- } \\
\text { likelihoods }\end{array}$ & $\begin{array}{c}\text { Pseudo } \\
\mathrm{R}^{2}\end{array}$ & $\chi^{2}$ \\
\hline $\begin{array}{c}\text { Basic } \\
\text { regression }\end{array}$ & $\mathrm{y}=5,09-0,078 \mathrm{x}_{1}+0,099 \mathrm{x}_{2}-0,039 \mathrm{x}_{3}-0,067 \mathrm{x}_{4}$ & $-12,543$ & 0,26 & 8,56 \\
\hline $\begin{array}{l}\text { Optimized } \\
\text { regression }\end{array}$ & $\mathrm{y}=45,63-0,71 \mathrm{x}_{1}+0,7759 \mathrm{x}_{2}-0,517 \mathrm{x}_{3}+0,694 \mathrm{x}_{4}$ & $-6,495$ & 0,61 & 20,63 \\
\hline
\end{tabular}

Based on regression coefficient signs is worth to notice that share of final consumption and share of exports in GDP have negative regression relationships with GDP growth, while volumes of remittances and imports vice versa. Optimization process increased sum log-likelihood value, what leads to greater adequacy of model by R-squared and chi-squared criterias. As a result, received chi-squared is greater than 9,49 and 13,28 critical values at 0,05 and 0,01 levels of significance. Graphic test of fitness also showed adequacy of built model (pic. 2).

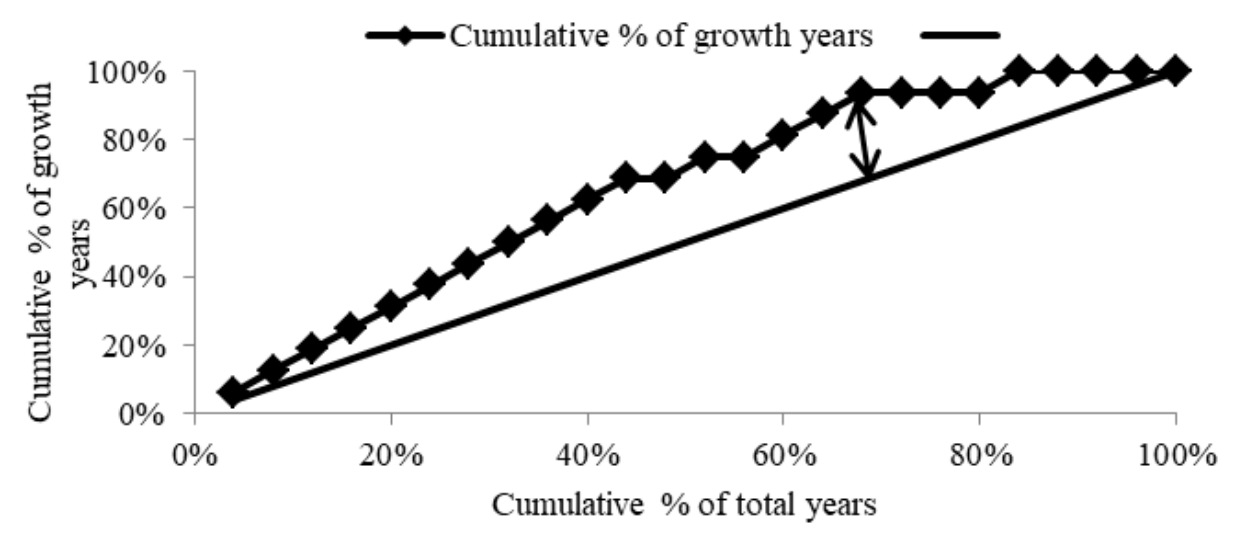

Pic. 2. Graphic test of fitness. Source: author research

In order to examine probability of economic growth after changes in remittances we are going to increase and decrease current value of the latter by maximum one standard deviation, which accounts $3,55 \%$ (tab.2).

Tab.2

Probabilities of economic growth in conditions of changing remittances. Source: author research

\begin{tabular}{|c|c|c|c|c|c|}
\hline $\begin{array}{l}\text { Change of } \\
\text { remittances, } \%\end{array}$ & $\begin{array}{c}\text { Remittances (\% } \\
\text { GDP) }\end{array}$ & $\begin{array}{l}\text { Probability of } \\
\text { GDP growth }\end{array}$ & $\begin{array}{c}\text { Final } \\
\text { consumption } \\
\text { expenditure (\% } \\
\text { of GDP) }\end{array}$ & $\begin{array}{l}\text { Exports of } \\
\text { goods and } \\
\text { services (\% of } \\
\text { GDP) }\end{array}$ & $\begin{array}{l}\text { Imports of goods and } \\
\text { services (\% of GDP) }\end{array}$ \\
\hline-3 & 7,35 & 0 & \multirow{6}{*}{95,23} & \multirow{6}{*}{41,17} & \multirow{6}{*}{49,00} \\
\hline-2 & 8,35 & 0 & & & \\
\hline-1 & 9,35 & 0 & & & \\
\hline 1 & 11,35 & 0 & & & \\
\hline 2 & 12,35 & 1 & & & \\
\hline 3 & 13,35 & 1 & & & \\
\hline
\end{tabular}

\section{Conclusions and future research}

Increase of remittances by 2 and more percent will lead to economic growth, ceteris paribus. In another case, economic growth is not expected. In conclusion, any government policy regarding regulation 
of remittance inflows might lead to decline of GDP, as scope of shadow economy will rise. Additionally, remittances can enter Ukraine in form of goods, what also can undermine domestic demand for Ukrainian goods.

The idea of the current article is to contribute to the debate regarding the influence of remmitances on the economic growth. From the calculations conducted in the article a conclusion can be made, that remmitances do contribute to the economics growth. At the same time, futher research requires to be conducted in order to check the mechanisms of remmitance influence on economic growth and definition of additional factors of impact.

\section{References}

1. Ale, S. A., Akter, R., and Islam, M. S. (2018). Remittance Inflow and GDP Growth: Evidence from Bangladesh, India and Pakistan. Asian Economic and Financial Review, 8(11), 1340.

2. Alonso-Rodríguez, A. (2001). Logistic regression and world income distribution. International Advances in Economic Research, 7(2), 231-242.

3. $\quad$ Barro, R. J. (2001). Human capital and growth. American economic review, 91(2), 12-17.

4. $\quad$ Cramer, J.S., The Origins of Logistic Regression (December 2002). Tinbergen Institute Working Paper No. 2002-119/4, Available at SSRN: https://ssrn.com/abstract=360300

5. Duguleană, C. (2019). Analysing The Contributions Of Economic Growth Factors In Romania. Bulletin of the Transilvania University of Brasov. Economic Sciences. Series V, 12(2), 145-156.

6. Hamberg, U., and Verständig, D. (2009). Applying logistic regression models on business cycle prediction. Unpublished master's thesis, Stockholm School of Economics, Stockholm, Sweden). Retrieved from http://arc. hhs. se/download. aspx.

7. Hassan, G. M., and Shakur, S. (2017). Nonlinear effects of remittances on per capita GDP growth in Bangladesh. Economies, 5(3), 25.

8. Hussain, R., and Anjum, G. A. (2014). Worker's remittances and GDP growth in Pakistan. International Journal of Economics and Financial Issues, 4(2), 376-381.

9. Javid, M., Arif, U., and Qayyum, A. (2012). Impact of remittances on economic growth and poverty. Academic Research International, 2(1), 433.

10. Kwasnicki, W. (2013). Logistic growth of the global economy and competitiveness of nations. Technological Forecasting and Social Change, 80(1), 50-76.

11. Le Heron, E., and Yol, N. (2019). The macroeconomic effects of migrants' remittances in Moldova: a stock-flow consistent model. European Journal of Economics and Economic Policies: Intervention, 16(1), 31-54.

12. Mankiw, N. G., Romer, D., and Weil, D. N. (1992). A contribution to the empirics of economic growth. The quarterly journal of economics, 107(2), 407-437.

13. Meyer, D., and Shera, A. (2017). The impact of remittances on economic growth: An econometric model. EconomiA, 18(2), 147-155.

14. Mincer, J. (1984). Human capital and economic growth. Economics of education review, 3(3), 195-

205.

15. Olubiyi, E. A. (2014). Trade, remittances and economic growth in Nigeria: Any causal relationship?. African Development Review, 26(2), 274-285.

16. Pelinescu, E. (2015). The impact of human capital on economic growth. Procedia Economics and Finance, 22(1), 184-190.

17. Pregibon, D. (1981). Logistic regression diagnostics. The Annals of Statistics, 9(4), 705-724.

18. Rahman, M. (2009). Contributions of exports, FDI and expatriates'remittances to real GDP of Bangladesh, India, Pakistan and Sri Lanka. Southwestern Economic Review, 36, 141-153.

19. Solow, R. M. (1988). Growth theory and after. The American Economic Review, 78(3), 307-317.

20. Weil, D. (2013). Economic Growth, $3^{\text {rd }}$ ed. Routlege.

21. World Development Indicators (2020).World Bank. Retrieved from: https://databank.worldbank.org/source/world-development-indicators 


\section{ЛОГІСТИЧНА РЕГРЕСІЯ ЯК ІНСТРУМЕНТ АНАЛІЗУВАННЯ ВПЛИВУ ПЕРЕКАЗІВ НА ЕКОНОМІЧНЕ ЗРОСТАННЯ}

\section{(С Олексів І.Б., Мірзоєва Д.Р., 2020}

У статті досліджено вплив грошових переказів на економічне зростання в Україні, оскільки їх обсяг зростає щороку та досягнув близько 11\% ВВП України, що у свою чергу може впливати на національну економіку. Аналіз літературних джерел продемонстрував, що вплив переказів на економіку може бути як позитивним, так i негативним залежно від макроекономічних параметрів. Оскільки Україна є країною з перехідною економікою результати дослідження може значно доповнити дану наукову дискусію. Через складнощі прогнозування конкретного рівня економічного зростання було застосовано логістичну регресію, яка демонструватиме лише ймовірність зростання економіки України. Її побудова була здійснена за допомогою оцінювання лінійної регресії методом МНК та оптимізацією ії параметрів для досягнення найбільшої сумарної точності моделі. Обсяги споживання, експорту та імпорту були включені до логістичної моделі як змінні, які формують ВВП та с внутрішніми факторами, а перекази як зовнішня змінна. Відповідно, результати засвідчили наявність позитивного регресійного зв'язку між переказами та імпортом та зростанням ВВП, а кінцеве споживання та експорт навпаки. Діагностика моделі за допомого псевдо коефіціснту детермінації засвідчила достатню для такого виду моделей адекватність на рівні 60\%. Графічний тест підтвердив адекватність моделі. Для моделювання впливу зміни рівня переказів на економічне зростання України було збільшено та зменшено їх рівень до величини максимум одного стандартного відхилення: на 1, 2 та $3 \%$ відповідно. Таким чином лише зростання рівня переказів на $2 \%$ призводить до економічного зростання при всіх інших рівних умовах. У результаті регулювання, яке може призвести до зменшення рівня переказів може потенційно сприяти зменшенню величини економічного зростання економіки України через зростання частки тіньового сектору національної економіки, зменшення попиту на вітчизняні товари тощо. Перспективами даного дослідження с його розширення у напрямі вивчення механізму впливу переказів на ВВП України та інших факторів впливу як на перекази, так і на економічне зростання.

Ключові слова: перекази, споживання, логістична регресія, економічне зростання 